\title{
Distribution, abundance, breeding parameters, threats and prey preferences of the eastern imperial eagle (Aquila heliaca) in European Turkey
}

\author{
Rozšírenie, početnost', hniezdne parametre, hrozby a potravné preferencie \\ orla král'ovského (Aquila heliaca) v európskej časti Turecka
}

\author{
Dimitar DEMERDZHIEV, Dobromir DOBREV, Süreyya ISFENDIYAROĞLU, Zlatozar BOEV, \\ Stoycho STOYCHEV, Nikolay TERZIEV \& Svetoslav SPASOV
}

\begin{abstract}
During the period 2008-2013, 32 different breeding territories were occupied by eastern imperial eagles (EIEs). These territories were mainly distributed in two regions: the Dervent Heights / Y1ldiz Mts. and the area to the north of the Marmara sea coast. The nearest neighbour distance established was $4.2 \mathrm{~km}$. The mean distance between pairs was $10.44 \pm 2.95 \mathrm{~km}$. The mean value of breeding success for the period 2008-2013, including 107 cases of incubation, was $1.01 \pm 0.10$. The mean breeding success of birds in the Marmara region (1.05 \pm 0.78$)$ was higher than that in the Dervent Heights / Y1ld1z Mts. (0.91 \pm 0.84$)$. The present study on the diet of the EIE was based on the remains of 582 prey items of at least 70 taxa. Mammals were the most common group (46.5\%), followed by birds (32.4\%) and reptiles $(20.3 \%)$. The white-breasted hedgehog (Erinaceus roumanicus) was the most common prey, followed by two tortoises - Hermann's tortoise (Eurotestudo hermanni) and the Greek tortoise (Testudo grae$c a$ ) - which together accounted for a total of $14.4 \%$ of the prey caught. The prey species particularly represented in the food spectrum of the studied pairs were: the yellow-legged gull (Larus michahellis), the European souslik (Spermophilus citellus), the chicken (Gallus gallus f. domestica) and the white stork (Ciconia ciconia). These species together accounted for $67.8 \%$ of the prey caught. There was a statistically significant difference $(Z=2.52, p=0.01)$ in the food preferences of the EIEs in the two studied regions.
\end{abstract}

\begin{abstract}
Abstrakt: V období 2008-2013 bolo orlami královskými obsadených 32 rôznych hniezdnych teritórií. Tieto územia sa nachádzajú najmä v dvoch oblastiach: pohorie Derventa / Yıldız a územie na sever od Marmarského mora. Najbližšia vzdialenost' medzi hniezdiskami bola 4,2 km. Stredná vzdialenost’ medzi pármi bola 10,44 $\pm 2,95 \mathrm{~km}$. Priemerná hodnota hniezdnej úspešnosti v ob-

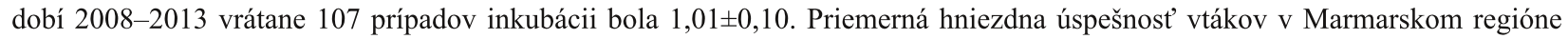
$(1,05 \pm 0,78)$ bola vyššia ako v oblasti pohorí Derventa/Yıldız $(0,91 \pm 0,84)$. Predkladaná štúdia potravy orla král'ovského bola založená na 582 zvyškoch koristi, obsahujúcej minimálne 70 taxónov. Cicavce boli najrozšírenejšie skupinou (46.5 \%), nasledované vtákmi (32,4 \%) a plazmi (20,3 \%). Najčastejšou korist’ou bol jež bledý (Erinaceus roumanicus) a dva druhy korytnačiek - korytnačka zelenkastá (Eurotestudo hermanni) a korytnačka grécka (Testudo graeca), ktoré dohromady predstavovali celkom $14,4 \%$ z ulovenej koristi. Potravné spektrum sledovaných párov obsahoval tieto druhy koristi: čajka žltonohá (Larus michahellis), sysel' pasienkový (Spermophilus citellus), domáca sliepka (Gallus gallus f. domestica) a bocian biely (Ciconia ciconia). Tieto druhy dohromady tvorili $67,8 \%$ z ulovenej koristi. Bol preukázaný štatisticky významný rozdiel $(Z=2,52, p=0,01)$ v preferencii potravy orlov král’ovských v oboch študovaných oblastiach.
\end{abstract}

Key words: population dynamics, diet, conservation measures

Dimitar Demerdzhiev, Dobromir Dobrev, 5 Leonardo da Vinci str., 4000 Plovdiv, Bulgaria. E-mail: dimitar.demerdzhiev@bspb.org.

Süreyya Isfendiyaroğlu, Ali Suavi str. No:14/4, Kadıköy, Istanbul, Turkey.

Zlatozar Boev, National Museum of Natural History, Bulgarian Academy of Sciences, 1, Blvd. Tsar Osvoboditel, 1000 Sofia, Bulgaria.

Stoycho Stoychev, Svetoslav Spasov, 71, Yavorov str., 1111 Sofia, Bulgaria.

Nikolay Terziev, Bul „23 Pehoten Shipchenski polk“ 68, et3, ap8, Kazanlak 6100, Bulgaria.

Acknowledgements: We would like to thank the Restoration and Development Union and PHARE CBC Program, LIFE+ Programme of the European Union for their financial support for the EIE research. Our thanks also go to Taner Chetin, Shukri Chetin, Selen Y1ldız, José Tavares, Ivaylo Angelov, Nedko Nedyalkov, Dimitar Hanev, Georgi Georgiev, Dimitar Plachiyski, Guy Anderson, Vladimir Trifonov, Atanas Demerdzhiev and Márton Horváth for providing valuable information about the species and participating in the field activities and research. 


\section{Introduction}

The eastern imperial eagle (Aquila heliaca) (EIE) is distributed in various regions of Turkey (Kirwan et al. 2008). Due to the lack of systematic surveys in the European part of the country, the species was considered to be breeding in isolated localities and to be on the brink of extinction (Warncke 1966, 1968, Wirth 1996, Gursan \& Bilgin 2002, Kirwan et al. 2008). However, the study carried out in 2008 and 2009 revealed a well-distributed and relatively abundant population of the species in European Turkey (Demerdzhiev et al. 2011c). The surveys implemented on either side of the state border proved that the EIE is represented in Thrace by a meta-population of about $60-75$ pairs distributed in south-eastern Bulgaria and European Turkey (Demerdzhiev et al. 2011a, b).

This article presents the distribution, numbers, breeding parameters, threats and food preferences of the EIE in the European part of Turkey, studied between 2008 and 2013. Thirty-two different occupied territories were discovered in the study period. The population was estimated at 35-45 pairs.

\section{Materials and methods}

\section{$\mathrm{S} t \mathrm{u} d \mathrm{y}$ a $\mathrm{r}$ e a $\mathrm{s}$}

The studies were carried out in Thrace (Lower Thrace Lowlands), except for wooded areas of the Yildiz Mts. The terrain is hilly and flat, with an altitude from $0-460 \mathrm{~m}$ above sea level. The natural vegetation is represented by forests, mainly of downy oak (Quercus pubescens), holm oak (Quercus ilex), Turkey oak ( $Q u$ ercus cerris) and manna ash (Fraxinus ornus) (Natcheva et al. 2008). Since the natural vegetation has been widely modified by anthropogenic activities, these ecosystems occupy isolated patches scattered among arable areas (Mayer \& Aksoy 1986). The shrubs of the Jerusalem thorn (Paliurus spina-christi) mixed with pistacia (Pistacia sp.), in combination with the xerothermal grass formations on dry pastures, provide suitable habitats for various bird species. Many of the riverbeds and valleys are still fringed by old trees of white poplar (Populus alba), willow (Salix sp.) and manna ash, which provide nesting conditions for birds of prey.

\section{F i e l d s u r v e y}

The occupied territories were monitored three times per breeding period (March-August) in each year. The first visit took place in March-April to identify the territories occupied by pairs. The monitoring conducted in May was aimed at recording the pairs that had started incubating. The breeding success was then recorded in July. Chicks at the age of more than 55 days were considered to be successfully reared. The search for new pairs and the inspection of suitable areas were carried out in March and April, when trees have no leaves and the nests are clearly visible from a great distance. Also, at that time of the year the eagles demonstrate clear territorial behaviour such as mating behaviour, display and defence of the breeding territory against other birds of prey. The inspections involved transect methods used mainly along river valleys or streams, or the examination of high trees in open habitats. Another method used during the inspections was observation from a viewpoint (Bibby et al. 1999, Andersen 2007). The surveys covered an area of $13,350 \mathrm{~km}^{2}$, accounting for about $83 \%$ of the territory suitable for EIE breeding. Occupied territories, breeding pairs, the age structure of the population and the population breeding parameters were recorded on an annual basis. We estimated the breeding success (number of fledglings / breeding pair) and success rate (frequency of breeding attempts with at least one fledged chick), including 114 breeding attempts. Brood size was also recorded. The identification of plumage was done according to Forsman (2005). The birds were considered adults in the sixth calendar year. The pairs were classified into three categories: adult consisting of two individuals in adult plumage; mixed consisting of an individual in immature plumage (second-fifth) and an adult partner (from sixth plumage up); and immature - consisting of two individuals in immature plumage.

F o o d s u r v e y

The material was collected in 2008-2011 from 18 nest sites. Each breeding site was visited after the fledglings had left the nest (August-September). Food remains, bones, feathers and pellets were collected inside and under nests and perches (Katzner et al. 2005). A total of 186 pellets were collected. The material amounted to 1,513 bones and bone fragments belonging to 582 individual specimens. The collected material was determined through the comparative osteological collections of the National Museum of Natural History at the Bulgarian Academy of Science. Whenever possible, the minimum number of individuals (MNI) in each pellet or prey remain was estimated from the number of skeletal or keratinized body parts present (Katzner et al. 2005). The MNI was determined by taking into account the age (juvenis, subadultus, adultus), sex and size differences between individuals. The body mass of the specimens of 
the various species was determined after Petrov (1964), Simeonov \& Petrov (1980), Boev (1986), Simeonov et al. (1990), Böhme (1993), Kunstmüller (2000), Dunning (2008) and Aulagner et al. (2009). The average body mass was calculated on the basis of the average mass of the individual specimens. When the material was identified at the genus level, the average values for the presented species of the genus were considered. The percentage values were read to the 2 nd digit after the decimal point. The carrion's biomass was not considered.

\section{Statis tica 1 a n a 1 y $\mathrm{s}$ is}

The statistical processing of data was carried out using the program Statistica for Windows, Release 7.0 (Statsoft 2004). The data was analysed for normal distribution through the Shapiro-Wilk test (Shapiro et al. 1968). Results with $\mathrm{p}<0.05[\alpha=5 \%]$ were considered significant. The non-parametric Mann-Whitney U-test and parametric T-test were used when comparing or seeking correlations between different variables.

\section{Results}

B r e e d ing distribution and

p o p u 1 a t i o $n$

During the period 2008-2013, 32 different breeding territories were occupied (Fig. 1). Territories were mainly located in two regions: the Dervent Heights / Yildız Mts. and the area to the north of the Marmara sea coast.

The region of the Dervent Heights/Yıldız Mts. harboured 13 breeding pairs distributed in 10 UTM squares. The EIEs from this region bred close to the Bulgarian border, avoiding the wooded areas of the Y11diz Mts. The second region was inhabited by 19 breeding pairs distributed in 17 UTM squares. During the study period, only one territory was lost and three newly formed pairs were recorded colonizing new territories (Fig. 2). In general, the birds were adult in $78 \%$ of the recorded cases of occupied territories, were mixed pairs in $19 \%$, and only in two territories were the birds in immature pairs. There is no precise data on the replacement rate of the breeders over the years. However, the

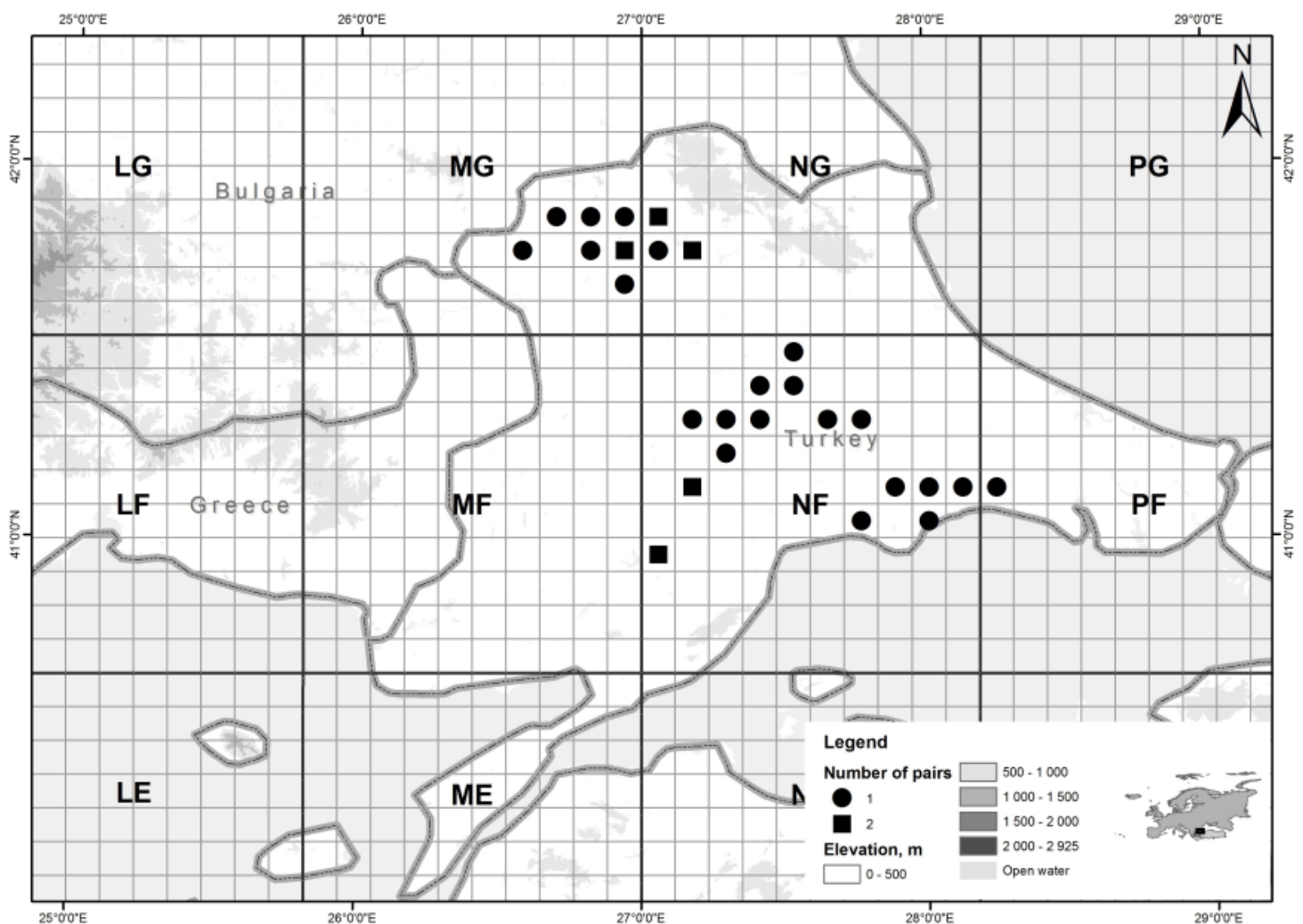

Fig. 1. Breeding distribution of eastern imperial eagle in the European part of Turkey between 2008 and 2013 (black square - two pairs, black circle - one pair).

Obr. 1. Hniezdne rozšírenie orlov král'ovských v európskej časti Turecka v rokoch 2008 a 2013 (čierny štvorec - dva páry, čierny krúžok - jeden pár). 
replacement of birds was recorded in at least four cases in four territories. The nearest neighbour distance established was $4.2 \mathrm{~km}$. The mean distance between pairs was $10.44 \pm 2.95 \mathrm{~km}$.

B reeding success, success $\mathrm{r}$ a t e a d b rood si z e

The mean value of breeding success for the period 2008-2013, including 107 cases of incubation, was $1.01 \pm 0.10$. The mean success rate was $69.2 \pm 46.4 \%$. During the period $2008-2013,40.5 \pm 13.4 \%$ of the pairs, on average, had two chicks each. The mean proportion of one-chick broods was $54.9 \pm 14.6 \%$. The frequency of three-chick broods was lower at $4.5 \pm 4.4 \%$. There was no statistically significant difference $(\mathrm{t}=0.86, \mathrm{df}=105, \mathrm{p}=0.39)$ between the breeding success of the pairs nesting in the Dervent Heights/Y1ld1z Mts. ( $n=46$ breeding attempts) and the pairs of the Marmara region ( $\mathrm{n}=61$ breeding attempts). However, the mean breeding success of birds in the Marmara region $(1.05 \pm 0.78)$ was greater than that in the other region $(0.91 \pm 0.84)$.

Mort a lity a nd threat $\mathrm{s}$

Brood mortality was surveyed between 2008 and 2013, including 38 breeding failures and the mortality of approximately 23 broods and 15 chicks (Tab. 1).

During the study periods, disturbance was among the major factors causing brood loss. Infertility was also one of the main reasons for breeding failure. The main reason for the loss of chicks during the study period was stormy weather and dropping from the nest. Cainism was reported in only one case of chick mortality. However, most of the cases of chick mortality remained unknown.

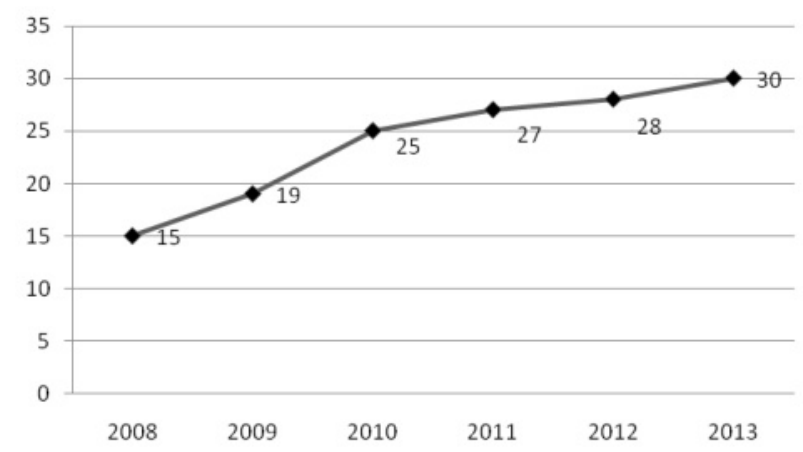

Fig. 2. Dynamics of the eastern imperial eagle population in period 2008-2013 (y axis - number of occupied territories).

Obr. 2. Dynamika populácie orlov král'ovských v období 2008-2013 (os y - počet obsadených teritórií).
Electrocution is one of the underestimated, but probably serious threats. Three of the immature eagles tagged with satellite transmitters in Bulgaria died as a result of electrocution in Turkey. Another juvenile EIE tagged with a satellite transmitter in European Turkey was found shot to the north of the town of Tekirdag. In the same region, a juvenile EIE tagged with a satellite transmitter in Bulgaria was recorded poisoned. Cutting of nest trees was also a serious threat. During the study period, three nest trees were found cut. Another such case was prevented shortly before the tree with the incubating eagle was to be cut. Treasure-hunting could be another reason for unsuccessful breeding. In 2008, the presence of treasure-hunters under one of the EIE nests built on an oak tree was the reason for the abandonment of the eggs.

F o o d p r e f e r e n c e s

The present study on the diet of the EIE was based on the remains of 582 prey items of at least 70 taxa. Mammals were the most common group with $46.5 \%$, followed by birds with $32.4 \%$ and reptiles with $20.3 \%$. In terms of biomass, birds provided $44.7 \%$, followed by mammals (37.9\%) and reptiles $(17.4 \%)$. The whitebreasted hedgehog (Erinaceus roumanicus) was the most common prey (Tab. 2), followed by two tortoise species - Hermann's tortoise (Eurotestudo hermanni) and the Greek tortoise (Testudo graeca) - which accounted for a total for $14.4 \%$ of the prey caught.

Both species were equally represented in the diet of the EIE. The prey species particularly represented in the food spectrum of the studied pairs were: the yellow-legged gull (Larus michahellis), the European souslik (Spermophilus citellus), the chicken (Gallus gallus f. domestica), and the white stork (Ciconia ciconia) (Tab. 2). All these species accounted for $67.8 \%$ of the prey caught. The species with the greatest contribution to the biomass were again the white-breasted hedgehog

Tab. 1. Brood mortality of eggs and chicks in period 2008-2013 Tab. 1. Mortalita vajec a mlád'at v období 2008-2013

\begin{tabular}{lcc}
\hline $\begin{array}{l}\text { mortality / } \\
\text { mortalita }\end{array}$ & $\begin{array}{c}\text { eggs / } \\
\text { vajcia }\end{array}$ & $\begin{array}{c}\text { chicks / } \\
\text { mlád'atá }\end{array}$ \\
\hline infertility / neplodnost' & $8 ; 35 \%$ & \\
disturbance / vyrušovanie & $9 ; 39 \%$ & \\
storm / búrka & $1 ; 4 \%$ & $3 ; 20 \%$ \\
unknown factors / neznáme faktory & $5 ; 22 \%$ & $8 ; 53 \%$ \\
cainism / kainizmus & & $1 ; 7 \%$ \\
dropping from the nest / & & $3 ; 20 \%$ \\
vypadnutie z hniezda & & \\
\hline
\end{tabular}


and the tortoises, followed by the yellow-legged gull, the white stork, the chicken, the European hare (Lepus europaeus), the red fox (Vulpes vulpes) and the European souslik. These components constituted $84.5 \%$ of the total biomass. There was a statistically significant difference $(\mathrm{Z}=2.52, \mathrm{p}=0.01)$ in the food preferences of the EIEs in the two studied regions. Almost half of the prey caught by eagles in the Dervent Heights / Yildiz Mts. were white-breasted hedgehogs (Tab. 2), followed by the tortoises, European sousliks, and yellow-legged gulls. In the Marmara region, the most common prey species was the yellow-legged gull, followed by the tortoises. However, the Greek tortoise was twice as common in the diet of the birds in the Marmara region compared with that of the Dervent Heights / Y1ldiz Mts. The European souslik was the third most common prey of EIEs in the Marmara region. The share of European souslik in the diet of the eagles in this region was twice as large as that in the Dervent Heights / Y1ldiz Mts. The white-breasted hedgehog ranked fourth among the prey species caught by the eagles in the Marmara region (Tab. 2). Also, an obvious difference in the food preferences of the eagles in the two regions was recorded in terms of voles. While accounting for $6.4 \%$ of the prey caught in the Marmara region, voles represented less than $1.0 \%$ in the Dervent Heights / Y 1 ldız Mts.

\section{Discussion}

The EIEs breeding in European Turkey belong to a metapopulation of the species distributed across Thrace (Bulgaria and Turkey) (Demerdzhiev et al. 2011a, b). In European Turkey, the EIE is well represented in the two distribution areas, occupying suitable territories. The present study did not confirm breeding of EIEs along the lower reaches of the Maritsa River, where the species occurred in the 1960s (Warncke 1966, 1968, Wirth 1996). However, we observed an immature individual in a suitable habitat. The results of this study show that the population of the species in European Turkey, like the one in Bulgaria (Demerdzhiev 2011, Demerdzhiev et al. 2011a, b), is gradually increasing. However, in European Turkey there is no precise assessment of the replacement rate, which is an indirect indicator of the mortality of breeding birds. In general, the breeding density of the EIE in European Turkey was similar to that reported from Bulgaria (Demerdzhiev 2011).

The EIE population in Bulgaria had better breeding success for the period 2009-2013, which was probably due to the higher percentage of two-chick broods (Demerdzhiev et al. 2014). The smaller brood size in
European Turkey was probably due to the limited food resources. Moreover, the pairs in European Turkey were exposed to many more disturbances than the birds breeding in Bulgaria. This was particularly valid for birds breeding in the Dervent Heights / Y1ldiz Mts. region. Most of the nest trees were located in small cornfields frequently visited by local farmers. Sometimes the eagles' nests are built at a height of only $6-8 \mathrm{~m}$ above the ground.

In general, the threats to the EIE in European Turkey have been insufficiently studied. Disturbance during the breeding season is one of the most important reasons for breeding failure. In Bulgaria, the guarding of nests during the breeding period increased the success rate by more than $20 \%$ and the breeding success of "risky" pairs by $35 \%$ (Demerdzhiev 2011). Electrocution is one of the factors probably causing high mortality, due to the fact that the power supply network in Turkey is made of facilities particularly dangerous for birds. The data gathered through satellite tracking of 20 juvenile EIEs from Bulgaria and two EIEs from European Turkey shows that more than half of the birds overwinter in different regions of Turkey. Since juvenile and immature birds are less experienced, they are exposed to a higher risk of electrocution. Juvenile EIEs from the Pannonian and the Macedonian population of the species also winter in Turkey (M. Horváth, E. Lisichanec, in litt.). Therefore, the insulation of hazardous electric poles in the wintering grounds in Turkey is crucial not only for the Thracian population of the EIE, but for the population of the species in Europe as well. The region to the north of the Sea of Marmara, located between the towns of Tekirdag and Çorlu, is an important stopover for EIEs during migration and a temporary settlement area during the winter period. The region harbours concentrations of five to twelve individuals in winter (author's unpubl. data). Therefore, this region is of global significance for the EIE. Four birds tagged with satellite transmitters were found dead in this region - one shot, one poisoned and the cause of death of the other two birds remains unknown. The recorded felling of nest trees is another factor limiting the population. In some suitable nesting habitats with abundant prey species the lack of suitable nest trees can be a limiting factor. Moreover, the birds may build a nest in the wrong unsafe place, which could result in breeding failure.

Since pastures are public property in Turkey, their land-use designation can be easily altered in the relevant management plans, and some of the key foraging habitats could be lost. Currently, some pastures are subject 
Tab. 2. Diet composition of eastern imperial eagle in the European part of Turkey ( $n$ - number of prey item, $p-p r e s e n c e, b-b i o m a s s)$

Tab. 2. Zloženie potravy orlov král'ovských v európskej časti Turecka ( $n$ - počet položiek koristi, $p$ - prezencia, b - biomasa)

\begin{tabular}{|c|c|c|c|c|c|c|c|c|c|}
\hline \multirow[b]{2}{*}{ taxa } & \multicolumn{3}{|c|}{ Dervent / Yıldız } & \multicolumn{3}{|c|}{ Marmara region } & \multicolumn{3}{|c|}{$\sum$} \\
\hline & $\mathbf{n}$ & $\mathbf{p}[\%]$ & b [\%] & $\mathbf{n}$ & $\mathbf{p}[\%]$ & b [\%] & $\mathbf{n}$ & $\mathbf{p}[\%]$ & b [\%] \\
\hline Orthoptera spp. & 1 & 0.45 & & & & & 1 & 0.17 & \\
\hline Coleoptera spp. & 2 & 0.90 & & 2 & 0.56 & & 4 & 0.69 & \\
\hline Pseudopus apodus & 5 & 2.24 & 1.01 & 7 & 1.95 & 0.91 & 12 & 2.06 & 0.96 \\
\hline Lacerta sp & 1 & 0.45 & 0.02 & & & & 1 & 0.17 & 0.01 \\
\hline Dolichophis caspius & 4 & 1.79 & 1.34 & 8 & 2.23 & 1.73 & 12 & 2.06 & 1.58 \\
\hline Elaphe sauromates & 1 & 0.45 & 0.33 & 1 & 0.28 & 0.22 & 2 & 0.34 & 0.26 \\
\hline Natrix natrix & 1 & 0.45 & 0.03 & & & & 1 & 0.17 & 0.01 \\
\hline Serpentes spp. & 1 & 0.45 & 0.33 & 4 & 1.11 & 0.87 & 5 & 0.86 & 0.66 \\
\hline Mauremys rivulata & & & & 1 & 0.28 & 0.14 & 1 & 0.17 & 0.09 \\
\hline Eurotestudo hermanni & 17 & 7.56 & 5.34 & 21 & 5.85 & 6.21 & 38 & 6.53 & 5.87 \\
\hline Testudo graeca & 9 & 4.04 & 4.01 & 29 & 8.08 & 8.23 & 38 & 6.53 & 6.57 \\
\hline Testudo spp. & 4 & 1.79 & 1.78 & 4 & 1.11 & 1.16 & 8 & 1.37 & 1.40 \\
\hline Anas platyrhynchos & & & & 1 & 0.28 & 0.32 & 1 & 0.17 & 0.19 \\
\hline Anser erythropus & 1 & 0.45 & 0.78 & & & & 1 & 0.17 & 0.31 \\
\hline Anser albifrons & & & & 1 & 0.28 & 0.82 & 1 & 0.17 & 0.50 \\
\hline Anser spp. & 2 & 0.90 & 0.96 & & & & 2 & 0.34 & 0.38 \\
\hline Ciconia ciconia & 8 & 3.59 & 12.29 & 11 & 3.06 & 10.67 & 19 & 3.26 & 11.30 \\
\hline Accipiter nisus & & & & 1 & 0.28 & 0.07 & 1 & 0.17 & 0.04 \\
\hline Aquila pomarina & & & & 1 & 0.28 & 0.40 & 1 & 0.17 & 0.24 \\
\hline Buteo rufinus & 1 & 0.45 & 0.41 & & & & 1 & 0.17 & 0.16 \\
\hline Falco tinnunculus & 1 & 0.45 & 0.08 & & & & 1 & 0.17 & 0.03 \\
\hline Athene noctua & 2 & 0.90 & 0.15 & 1 & 0.28 & 0.05 & 3 & 0.52 & 0.09 \\
\hline Asio otus & & & & 2 & 0.56 & 0.17 & 2 & 0.34 & 0.10 \\
\hline Gallus gallus f. domestica & 6 & 2.69 & 7.35 & 19 & 5.29 & 12.57 & 25 & 4.30 & 10.51 \\
\hline Meleagris gallopavo f. domestica & 3 & 1.35 & 5.34 & 2 & 0.56 & 2.31 & 5 & 0.86 & 3.50 \\
\hline Phasianus colchicus & & & & 1 & 0.28 & 0.32 & 1 & 0.17 & 0.19 \\
\hline Cairina moschata & & & & 2 & 0.56 & 1.42 & 2 & 0.34 & 0.86 \\
\hline Larus michahellis & 10 & 4.48 & 5.14 & 60 & 16.71 & 19.39 & 70 & 12.03 & 13.79 \\
\hline Streptopelia decaocto & 1 & 0.45 & 0.07 & & & & 1 & 0.17 & 0.03 \\
\hline Columba palumbus & 1 & 0.45 & 0.22 & & & & 1 & 0.17 & 0.09 \\
\hline Cuculus canorus & 1 & 0.45 & 0.05 & & & & 1 & 0.17 & 0.02 \\
\hline Oenanthe oenanthe & 1 & 0.45 & 0.01 & & & & 1 & 0.17 & \\
\hline Turdus philomelos & & & & 1 & 0.28 & 0.02 & 1 & 0.17 & 0.01 \\
\hline Carduelis cannabina & & & & 1 & 0.28 & 0.01 & 1 & 0.17 & \\
\hline Sturnus vulgaris & 3 & 1.35 & 0.11 & 3 & 0.84 & 0.07 & 6 & 1.03 & 0.09 \\
\hline Paser hispaniolensis & 1 & 0.45 & 0.01 & & & & 1 & 0.17 & \\
\hline Passer montanus & & & & 2 & 0.56 & 0.01 & 2 & 0.34 & 0.01 \\
\hline
\end{tabular}

to afforestation, especially in the western part of the species' range (Isfendiyaroğlu 2012).

Turkey's major investments, such as the third Bosporus Bridge, the third Istanbul airport and the Canal Istanbul Project, which is planned to connect the Black Sea to the Marmara Sea, may result in the establishment and/or expansion of urbanized areas in Thrace. This is particularly valid for the territories in the Marmara Region, which, being located in the vicinities of populated areas, may be more likely to be affected by the expansion of the city centres. The establishment of wind power plants is another threat that could adversely affect the population, although the possible impacts of this in- frastructure in the region have not been properly assessed (Isfendiyaroğlu 2012).

The effective conservation of the EIE in the European part of Turkey requires the implementation of a monitoring program, the gathering of information about the population status, detailed studying of the threats, detection of previously unknown breeding pairs as well as the realization of an awareness raising campaign among hunters and local people, emphasizing the significance of the EIE and the importance of the region for the population of this species.

In terms of food preferences, the EIE is an opportunistic species. Our data suggests that four prey compo- 
Tab. 2. continuation

Tab. 2. pokračovanie

\begin{tabular}{|c|c|c|c|c|c|c|c|c|c|}
\hline \multirow[b]{2}{*}{ taxa } & \multicolumn{3}{|c|}{ Dervent / Yıldız } & \multicolumn{3}{|c|}{ Marmara region } & \multicolumn{3}{|c|}{$\sum$} \\
\hline & $\mathbf{n}$ & $\mathbf{p}[\%]$ & b [\%] & $\mathbf{n}$ & $p[\%]$ & b [\%] & $\mathbf{n}$ & p [\%] & b [\%] \\
\hline Passer sp. & & & & 1 & 0.28 & 0.01 & 1 & 0.17 & \\
\hline Emberiza sp. & & & & 1 & 0.28 & 0.01 & 1 & 0.17 & 0.01 \\
\hline Alauda arvensis & 1 & 0.45 & 0.02 & & & & 1 & 0.17 & 0.01 \\
\hline Oscines non-Corvidae & 1 & 0.45 & 0.05 & 2 & 0.56 & 0.07 & 3 & 0.52 & 0.06 \\
\hline Corvus corax & 1 & 0.45 & 0.35 & 3 & 0.84 & 0.68 & 4 & 0.69 & 0.55 \\
\hline Corvus monedula & 3 & 1.35 & 0.33 & 5 & 1.39 & 0.36 & 8 & 1.37 & 0.34 \\
\hline Corvus frugilegus & & & & 7 & 1.95 & 0.92 & 7 & 1.2 & 0.56 \\
\hline Corvus cornix & 3 & 1.35 & 0.76 & 1 & 0.28 & 0.16 & 4 & 0.69 & 0.40 \\
\hline Pica pica & 2 & 0.90 & 0.18 & 6 & 1.67 & 0.36 & 8 & 1.37 & 0.29 \\
\hline Garrulus glandarius & & & & 1 & 0.28 & 0.05 & 1 & 0.17 & 0.03 \\
\hline Erinaceus roumanicus & 91 & 40.81 & 35.12 & 43 & 11.98 & 12.29 & 134 & 23.10 & 21.27 \\
\hline Crocidura leucodon & & & & 1 & 0.28 & 0.01 & 1 & 0.17 & \\
\hline Crocidura suaveolens & & & & 1 & 0.28 & & 1 & 0.17 & \\
\hline Lepus europaeus & 4 & 1.79 & 6.91 & 6 & 1.67 & 6.15 & 10 & 1.72 & 6.45 \\
\hline Dryomys nitedula & & & & 1 & 0.28 & 0.01 & 1 & 0.17 & 0.01 \\
\hline Spermophilus citellus & 15 & 6.73 & 1.74 & 47 & 13.06 & 3.53 & 62 & 10.65 & 2.82 \\
\hline Microtus arvalis & & & & 4 & 1.11 & 0.03 & 4 & 0.69 & 0.02 \\
\hline Microtus guentheri & & & & 6 & 1.67 & 0.12 & 6 & 1.03 & 0.07 \\
\hline Microtus subterraneus & & & & 5 & 1.39 & 0.04 & 5 & 0.86 & 0.03 \\
\hline Microtus rossiaemeridionalis & & & & 4 & 1.11 & 0.03 & 4 & 0.69 & 0.02 \\
\hline Microtus sp. & 1 & 0.45 & 0.01 & 4 & 1.11 & 0.03 & 5 & 0.86 & 0.03 \\
\hline Micromys minutus & & & & 3 & 0.84 & 0.01 & 3 & 0.52 & \\
\hline Mus musculus & & & & 1 & 0.28 & 0.01 & 1 & 0.17 & 0.01 \\
\hline Mus macedonicus & & & & 4 & 1.11 & 0.04 & 4 & 0.69 & 0.02 \\
\hline Mus sp. & & & & 1 & 0.28 & 0.01 & 1 & 0.17 & 0.01 \\
\hline Rattus norvegicus & & & & 1 & 0.28 & 0.06 & 1 & 0.17 & 0.04 \\
\hline Nanospalax leucodon & 5 & 2.24 & 0.41 & 3 & 0.84 & 0.16 & 8 & 1.37 & 0.26 \\
\hline Canis sp. & 2 & 0.90 & 2.57 & & & & 2 & 0.34 & 1.01 \\
\hline Canis aureus & & & & 1 & 0.28 & 0.72 & 1 & 0.17 & 0.44 \\
\hline Canis familiaris & 1 & 0.45 & 1.11 & 1 & 0.28 & 0.72 & 2 & 0.34 & 0.88 \\
\hline Vulpes vulpes & 2 & 0.90 & 3.28 & 5 & 1.39 & 5.32 & 7 & 1.20 & 4.51 \\
\hline Capra hircus domestica & 2 & 0.90 & & 1 & 0.28 & & 3 & 0.52 & \\
\hline Bos taurus domestica & & & & 1 & 0.28 & & 1 & 0.17 & \\
\hline Ovis musimon & 1 & 0.45 & & & & & 1 & 0.17 & \\
\hline Capra hircus domestica / Ovis aries domestica & & & & 2 & 0.56 & & 2 & 0.34 & \\
\hline$\sum$ & 223 & 100 & 100 & 359 & 100 & 100 & 582 & 100 & 100 \\
\hline
\end{tabular}

nents - the white-breasted hedgehog, tortoises, the yellow-legged gull, and the European souslik - play an especially important role in the diet of the EIEs from the European part of Turkey. The chicken, the white stork and rodents are also very important. The whitebreasted hedgehog, the European souslik and the white stork are typical prey species for the EIE population in Bulgaria (Demerdzhiev 2011). Tortoises are an alternative food source, proving the adaptability of the species. The share of tortoises in the diet of the neighbouring breeding pairs in Bulgaria is less than $1 \%$ (Demerdzhiev 2011). However, tortoises are represented by a high percentage in the food spectrum of EIEs from the population in the FYR of Macedonia (E. Lisichanec pers. comm.). Habitat differences can explain the bigger share of the Greek tortoise in the diet of EIEs in the Marmara region than in that of the birds in the Dervent Heights / Y1ldiz Mts. region. The habitat of the Marmara region consists of plains areas with a mosaic of arable lands, some pastures and small rivers and streams. In Bulgaria, the Greek tortoise inhabits mainly open grasslands, unlike Hermann's tortoise, for which thin woods is typical (Beshkov, Nanev 2002). The high percentage of yellow-legged gulls, especially in the diet of the pairs in the Marmara region, can be attributed to the proximity of the sea. Large flocks of dozens of gulls 
foraging in this region are found inland at a distance of about $50 \mathrm{~km}$ and more from the coast and are an abundant food source used by the eagles. This diet shift towards yellow-legged gulls is another example of the foraging adaptability of EIEs. In Bulgaria, one of the EIE pairs breeding at a distance of $50 \mathrm{~km}$ from the Black Sea feeds mostly on yellow-legged gulls (Demerdzhiev 2011). What is particularly interesting is the low share of the European hare in the diet of the eagles in European Turkey. In Bulgaria, the European hare is the fourth most common prey of the EIE, and, together with the white-breasted hedgehog, accounts for the highest percentage of the biomass. The European hare is the most important prey of the diet in the Pannonian Basin (Chavko et al. 2007, Horvath et al. 2010, Horal 2011, Wichmann 2011), where its share has increased over the years. The low representation of the European hare as a prey of the EIE is probably due to the low density of the species in European Turkey.

\section{References}

Andersen DE 2007: Survey techniques, 89-100. In: Bird DM \& Bildstein KM (eds): Raptor research and management techniques. Hancock House Publishers, Surrey, Canada \& Blain, WA, USA, 464.

Aulagnier S, Haffner R, Mitchell-Jones A, Moutou F \& Zima J 2009: Mammals of Europe, North Africa and the Middle East. A\&C Black Publishers Ltd., Paris, 272.

Beshkov V \& Nanev K 2002: Zemnovodni i vlechugi $\mathrm{v}$ Balgariya [Amphibians and reptiles in Bulgaria]. Pensoft publishing house. Sofia, 120. [In Bulgarian]

Bibby C, Jones M \& Marsden S 1999: Expedition field techniques. Bird surveys. Royal Geographical Society, London, 137.

Boev Z 1986: Sravnitelno-morfologichni prouchvaniya na chaplite (sem. Ardeidae - Aves) ot Balgariya [Comparative morphological studies on herons (fam. Ardeidae - Aves) from Bulgaria]. PhD thesis. University, Sofia, 193. [In Bulgarian]

Böhme W 1993: Äskulapnatter (E. longisima Laurenti 1768), 331-372. In: Böhme W (ed), Handbuch der Reptilien und Amphibien Europas. Aula Verlag, Weisbaden, 479.

Chavko J, Danko Š, Obuch J \& Mihók J 2007: The food of the imperial eagle (Aquila heliaca) in Slovakia. Slovak Raptor Journal 1: 1-18. DOI: 10.2478/v10262-012-0001-y.

Demerdzhiev D 2011: Iztochniyat tsarski orel (Aquila heliaca heliaca Savigny, 1809) (Accipitridae -
Aves) v Balgariya - razprostranenie, biologiya, ekologiya, chislenost i merki za opazvane [Eastern imperial eagle (Aquila heliaca heliaca Savigny, 1809) (Accipitridae - Aves) in Bulgaria - distribution, biology, ecology, numbers, and conservation measures]. Synopsis of the PhD. thesis. BASNMNH, Sofia, 39. [In Bulgarian]

Demerdzhiev D, Horváth M, Kovács A, Stoychev S \& Karyakin I 2011a: Status and population trend of the eastern imperial eagle (Aquila heliaca) in Europe in the period 2000-2010. Acta zoologica Bulgarica Supplementum 3: 5-14.

Demerdzhiev D, Gradev G, Stoychev S, Ivanov I, Petrov T \& Marin S 2011b: Increase of the population of the eastern imperial eagle (Aquila heliaca) in Bulgaria. Acta zoologica Bulgarica Supplementum 3: 41-54.

Demerdzhiev D, Stoychev S, Terziev N \& Angelov I 2011c: Status of the eastern imperial eagle (Aquila heliaca) in the European part of Turkey. Acta zoologica Bulgarica Supplementum 3: 87-93.

Demerdzhiev D, Stoychev S, Dobrev D, Spasov S \& Terziev N 2014: Undertaken conservation measures improving the population status of eastern imperial eagle (Aquila heliaca) in Bulgaria. Slovak Raptor Journal 8(1): 27-39. DOI: 10.2478/srj-2014-0007.

Dunning J (ed) 2008: Handbook of avian body masses. CRC Press, Taylor \& Francis Group, 655.

Forsman D 2005: Eastern imperial eagle plumages. Alula 4: 147-152.

Gursan M \& Bilgin C 2002: The status of the imperial eagle (Aquila heliaca) in Turkey. Aquila 107-108: 187-192.

Horal D 2011: Eastern imperial eagle Aquila heliaca in the Czech Republic. Acta Zoologica Bulgarica Supplementum 3: 55-59.

Horváth M, Szitta T, Firmanszky G, Solti B, Kovács A \& Moskat C 2010: Spatial variation in prey composition and its possible effect on reproductive success in an expanding eastern imperial eagle (Aquila heliaca) population. Acta Zoologica Academiae Scientiarum Hungaricae 56(2): 187-200.

Isfendiyaroğlu S 2012: Türk Trakya'da Doğu şah kartal (Aquila heliaca Savigny, 1809) üzerinde araştırmalar [Investigations on eastern imperial eagle (Aquila heliaca Savigny, 1809) in Turkish Thrace]. Master thesis. Istanbul University Institute of Sciences, Istanbul. [In Turkish]

Katzner T, Bragin E, Knick S \& Smith A 2005: Relationship between demographics and diet specificity 
of eastern imperial eagle Aquila heliaca in Kazakhstan. Ibis 147: 576-586. DOI: 10.1111/j.1474919X.2005.00443.x.

Kirwan G, Boyla K, Castell P, Demirci B, Ozen M, Welch H \& Marlow T 2008: The birds of Turkey. The distribution, taxonomy and breeding of Turkish birds. Christopher Helm, London, 512.

Kunstmüller I 2000: The food ecology and the diet composition of eagle owl (Bubo bubo) at the breeding sites in the Bohemian-Moravian highlands, Czech Republic. Crex 16: 50-59.

Mayer H \& Aksoy H 1986: Waelder der Türkei. Gustav Fischer, Stuttgart, 275.

Natcheva R, Coşkun M \& Çayır A 2008: Contribution to the bryophyte flora of European Turkey. Phytologia Balcanica 14(3): 335-341.

Petrov P. 1964: Variabiolnost v tegloto na zaeka (Lepus europaeus, Pall.) v Balgariya [Variability in the weight of common hare (Lepus europaeus, Pall.) in Bulgaria]. Forestry science 1(4): 73-81. [In Bulgarian]

Shapiro S, Wilk M \& Chen H 1968: A comparative study of various tests of normality. Journal of the American Statistical Association 63: 1343-1372. DOI: $10.1080 / 01621459.1968 .10480932$.
Simeonov S, Michev T \& Nankinov D 1990: Fauna na Balgariya. T 20, Aves, 1 [Fauna of Bulgaria. T 20, Aves, 1]. BAS, Sofia, 350. [In Bulgarian]

Simeonov S \& Petrov T 1980: Prouchvane varhu hranata na krastatiya orel (Aquila heliaca Savigny), obiknoveniya mishelov (Buteo buteo L.) i gashtatiya mishelov (Buteo lagopus Brünnich) v Balgariya [Study on food spectrum of imperial eagle (Aquila heliaca Savigny), common buzzard (Buteo buteo L.) and rough-legged buzzard (Buteo lagopus Brünnich) in Bulgaria]. Ecology 7: 22-30. [In Bulgarian]

StatSoft 2004: STATISTICA (data analysis software system), version 7. www.statsoft.com.

Warncke K 1966: Erganzungen zu meinen vogelkundlichen Beobachtungen in der Turkei. Vogelwelt 87: 188-189.

Warncke K 1968: Nachwinterliche Beobachtungen an turkischen Brutvogeln. Vogelwelt 2: 89-102.

Wichmann G 2011: The situation of the eastern imperial eagle Aquila heliaca in Austria. Acta Zoologica Bulgarica Supplementum 3: 37-40.

Wirth H 1996: Breeding record of the imperial eagle, Aquila heliaca, in Turkey. Zoology in the Middle East 12: 47-52. DOI:10.1080/09397140.1996.10637687. 